\title{
Review
}

\section{Lycopene: Implications for Human Health-A Review}

\author{
Lynda M. Doyle, MS, MBA* \\ Human Nutrition, Avant Nutrition, LLC, Rockaway, NJ 07866, USA \\ *Corresponding author \\ Lynda M. Doyle, MS, MBA \\ President and CEO, Human Nutrition, Avant Nutrition, LLC, Rockaway, NJ 07866, USA; E-mail: lyndamdoyle@gmail.com
}

Article information

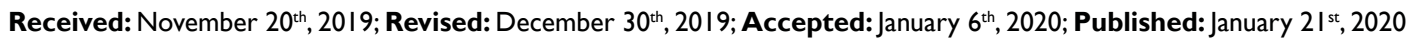

Cite this article

Doyle LM. Lycopene: Implications for human health-A review. Adv Food Technol Nutr Sci Open J. 2020; 6(I): I-I2. doi: 10.17|40/AFTNSOJ-6-I63

\section{ABSTRACT}

Lycopene is one of the six major dietary and serum carotenoids, and a potent antioxidant and anti-inflammatory agent. A large and growing body of scientific evidence supports the role of lycopene in multiple areas of health, including cancer, prostate, cardiometabolic, lung, skin, and liver health, and elucidates lycopene's mechanisms of action. This paper provides an overview of several benefit areas, specifically prostate, testes, cardiovascular, liver and skin health.

\section{Keywords}

Lycopene; Carotenoids; Cardiovascular disease (CVD); Human health.

\section{INTRODUCTION /}

C arotenoids are naturally occurring, generally fat-soluble pigments synthesized by plants, algae, and photosynthetic bacteria. Over 750 carotenoids are found in nature ${ }^{1}$ and 1,117 are catalogued in the Carotenoids Database. ${ }^{2}$ Carotenoids are responsible for the yellow, orange, and red colors in nature. Of the 40-50 carotenoids found in the human diet, lycopene is among the 6 most common dietary carotenoids, including $\alpha$-carotene, $\beta$-carotene, $\beta$-cryptoxanthin, lutein, and zeaxanthin. These are grouped into provitamin A carotenoids ( $\alpha$-carotene, $\beta$-carotene, $\beta$-cryptoxanthin) and non-provitamin A carotenoids (lycopene, lutein, and zeaxanthin). Lycopene contains 11 conjugated and 2 unconjugated double bonds and undergoes cis-trans isomerization through light, thermal energy and chemical reactions. ${ }^{3}$

Lycopene is present in orange-red fruits and vegetables, such as tomatoes, papayas, red peppers, pink grapefruit, and watermelons. The highest natural concentration is found in gac fruit, from a tropical vine in Southeast Asia. ${ }^{4}$ Tomatoes and tomatobased products, such as ketchup, tomato juice, tomato paste and tomato sauce, provide at least $80 \%$ of dietary lycopene in western countries such as the United States. ${ }^{5-7}$ The average daily consumption of lycopene in the western world is $5-7 \mathrm{mg} .{ }^{8}$ Lycopene from highly processed tomatoes is more bioavailable than that from raw tomatoes. ${ }^{9}$ Cooking and processing help release the lycopene from its plant matrix $^{8}$ and convert lycopene from its natural straight (trans) structure to a more bioavailable geometric (cis) isomer, ${ }^{10-13}$ because lycopene is fat soluble, dietary fat improves absorption. ${ }^{14}$

Since the human body cannot synthesize lycopene, it must be consumed in the diet or taken as a dietary supplement. A significant portion of intact lycopene is absorbed by humans, which circulates through and accumulates in the liver, plasma and other tissues. Lycopene is first emulsified and solubilized into micelles before absorbed into the intestinal mucosa, then transported with other dietary lipids via chylomicrons through the lymphatic system to the blood. Lycopene is the most predominant carotenoid in the plasma ${ }^{15}$ and concentrates in low-density and very-low-density lipoprotein fractions of serum due to its lipophilic nature. ${ }^{6,16}$ Lycopene is found in most human tissues with preferential accumulation in the testes, adrenal glands, liver and prostate..$^{15,17}$

Major health problems nowadays deal with the accumulation of reactive oxygen species (ROS) accompanied with abnormalities, such as inflammation and irregular lipid metabolism, that are the primary risk factor for the increased prevalence of lifestyle metabolic diseases. ROS, also called free radicals, are highly reactive, unstable molecules that contain oxygen, and a build-up of these may cause damage to deoxyribonucleic acid (DNA), ribonucleic acid (RNA), and proteins, and ultimately may cause cell death. With 11 conjugated double bonds, lycopene is one of the most potent antioxidants and free radical scavengers ${ }^{18-23}$ with stronger antioxidant properties than other serum carotenoids. ${ }^{24,25}$ Lycopene has the highest singlet oxygen quenching rate of the carotenoids, specifically twice that of $\beta$-carotene and 10 times greater than 
$\alpha$-tocopherol. ${ }^{26,27}$ By reducing the burden of ROS and oxidative stress, lycopene has been shown to prevent oxidative damage to lipids, proteins and cells. ${ }^{5,28}$

\section{PROSTATE HEALTH}

Prostate cancer is the second most frequently diagnosed cancer in men globally and the fifth leading cause of death worldwide. ${ }^{29}$ In the United States, after skin cancer, prostate cancer is the second most common cancer in men, accounting for $9.5 \%$ of all new cancer cases. ${ }^{30,31}$ The primary risk factors are obesity, age, and family history. Positive prostate health outcomes have been associated with dietary intake of tomatoes, tomato-based products and lycopene supplementation, and lycopene blood levels. ${ }^{32-35}$ In a dose-response meta-analysis of lycopene and prostate cancer research, Chen, et al demonstrated that higher lycopene consumption between 9 and $21 \mathrm{mg} /$ day and higher circulating levels of lycopene between 2.17 and $85 \mu \mathrm{g} / \mathrm{dL}$ were associated with a reduced risk of prostate cancer. ${ }^{34}$ Both lycopene supplementation (15 mg/d for 6-months) and consumption of lycopene-rich foods for 6 -months have been shown to increase mean lycopene $(1.28 \times$ and $1.42 \times$ higher, respectively, compared to placebo $)$ in men with elevated prostate-specific antigen (PSA) levels. ${ }^{36}$ Circulating pyruvate levels are associated with an increased risk of prostate cancer. Lycopene supplementation $(15 \mathrm{mg} / \mathrm{d}$ for 6-months) decreased circulating pyruvate levels in men with elevated PSA levels. ${ }^{37}$

Oxidative stress plays a role in prostate cancer by in- creasing ROS and cancer cell proliferation, thus causing somatic DNA mutations and increased angiogenesis. ${ }^{38}$ In addition to its ability to quench free radicals, lycopene may reduce the risk of prostate cancer by additional mechanisms. Lycopene impacts intercellular communication modulation and the alteration of intracellular signaling pathways, ${ }^{14}$ which include an upregulation in intercellular gap junctions, ${ }^{39}$ an increase in cellular differentiation, ${ }^{40}$ and alterations in phosphorylation of some regulatory proteins. ${ }^{41}$ Physiological concentrations of lycopene have been shown to inhibit cell line proliferation in combination with $\alpha$-tocopherol ${ }^{42}$ and lycopene was shown to inhibit prostate cancer cell proliferation via PPAR-LXRa-ABCA1 pathway. ${ }^{43}$ Lycopene attenuates the risk of prostate cancer by modulating the expression of growth and survival associated genes, e.g. CDK7, BCL2, EGFR, and IGF$1 \mathrm{R} .{ }^{44}$ Multiple lycopene doses showed significant improvement in survival rate of and significant reduction of tumor volume in mice injected with prostate cancer cell lines. ${ }^{45}$

\section{Male Infertility}

Infertility affects an estimated 70 million people globally, ${ }^{46}$ where male infertility contributes to $50 \%$ of the cases, according to the World Health Organization (WHO). Evidence suggests that oxidative stress caused by excessive amounts of ROS plays a role in idiopathic male infertility. ${ }^{47}$ This results in sperm membrane lipid peroxidation, DNA damage, and apoptosis leading to decreased sperm viability and motility. ${ }^{48}$ Lycopene concentration in testes is significantly lower in infertile men. ${ }^{49}$ Supplementation has been shown to increase seminal plasma lycopene, ${ }^{50}$ and lycopene may

\begin{tabular}{|c|c|c|c|}
\hline Authors & Population & Lycopene Dose & Results \\
\hline Aly $\mathrm{H}$ et al. ${ }^{56}$ & Wistar rats & $4 \mathrm{mg} / \mathrm{kg}$ bw, I6-days & $\begin{array}{l}\text { Significant prevention of } \\
\text { - Testes weight reduction } \\
\text { - } \downarrow \text { in sperm count, motility, viability and daily sperm production } \\
\text { - activation of Caspase- } 3 \text { and }-9\end{array}$ \\
\hline Nouri $M$ et al. ${ }^{58}$ & 44 infertile men & 25 mg lycopene, 12-weeks & $\begin{array}{l}\text { Lycopene group significant } \uparrow \text { total sperm count and concentration }(p<0.05) \\
\text { Within group significant } \uparrow \text { ejaculate volume, total sperm count, concentration and motility } \\
\text { Significant } \uparrow \operatorname{TAC}(p<0.05)\end{array}$ \\
\hline Tripathy A et al. ${ }^{57}$ & $\begin{array}{l}\text { Adult proven-fertile } \\
\text { male Wistar rates }\end{array}$ & $\begin{array}{l}1.5 \mathrm{mg} / 0.5 \mathrm{ml} \\
\text { Tween-80/100 g bw/d } \\
\text { 30-days }\end{array}$ & $\begin{array}{l}\text { Significant recovery in } \\
\text { - Sperm count and motility, HOS tail-coiled spermatozoa }(p<0.00 \mathrm{I}) \\
\text { - Testicular } \Delta 5,3 \beta-\mathrm{HSD}, 17 \beta-\mathrm{HSD} \text { activities }(p<0.05) \\
\text { - Catalase }(p<0.02 \text { in testis, } p<0.05 \text { in sperm) } \\
\text { - SOD }(p<0.05 \text { in testis and sperm) } \\
\text { - CD, MDA }(p<0.02) \\
\text { - Testicular cholesterol }(p<0.05) \\
\text { - Serum testosterone }(p<0.05) \\
\text { - Gene expression of testicular apoptic markers (Bax } p<0.02, \mathrm{Bcl}-2 \& \text { Caspase-3 } p<0.05) \\
\text { - Gene expression of testicular androgenic enzymes }(\Delta 5 \& 3 \beta-\mathrm{HSD} p<0.02,17 \beta-\mathrm{HSD} \\
p<0.05) \\
\text { - SGOT, SGPT }(p<0.05)\end{array}$ \\
\hline Xu $Q$ et al. ${ }^{35}$ & Male Wistar rats & $4 \mathrm{mg} / \mathrm{kg}$ bw, 60-days & $\begin{array}{l}\text { Inhibited BaP-caused decrease in sperm motility and concentration, increase in head, tail } \\
\text { and total abnormal sperm rate } \\
\downarrow \text { MDA, ROS, TBARS } \\
\uparrow \mathrm{GPx}, \mathrm{GSH} / \mathrm{GSSG}, \mathrm{CAT} \text {, SOD }\end{array}$ \\
\hline Beynon RA et al. ${ }^{37}$ & $\begin{array}{l}133 \text { human men } \\
50-69-\text { years with } \\
\text { elevated PSA }\end{array}$ & $\begin{array}{l}\text { I5 mg (capsules, blinded), } \\
\text { lycopene-rich foods, } \\
\text { unblinded, } 6 \text { months }\end{array}$ & $\downarrow$ Circulating pyruvate (higher levels linked to higher PCA risk) \\
\hline Jiang $L$ et al. ${ }^{45}$ & Male mice & $0, \mathrm{I}, 5$, or $10 \mathrm{mg} / \mathrm{kg}$ & $\begin{array}{l}\text { Significant improvement }(p<0.01) \text { in survival rate } \\
\text { Significant } \downarrow \text { tumor volume }(p<0.00 \text { I) all doses } \\
\downarrow \text { in serum inflammatory markers (ILI, IL6, IL8, and TNF- } \alpha \text { ) dose dependent }\end{array}$ \\
\hline Lane JA et al. ${ }^{36}$ & $\begin{array}{l}133 \text { human men } \\
50-69 \text {-years with } \\
\text { elevated PSA }\end{array}$ & $\begin{array}{l}15 \mathrm{mg} \text { (capsules, blinded), } \\
\text { lycopene-rich foods, } \\
\text { unblinded, 6-months }\end{array}$ & $\uparrow$ mean lycopene $1.28 x$ higher in capsule and $1.42 x$ higher in food than placebo \\
\hline
\end{tabular}


play a role as an antioxidant in the process of spermatogenesis. ${ }^{49}$

Multiple lycopene supplementation studies have shown promising results in reducing male infertility in both human and animal models. Results include a decrease in lipid peroxidation and DNA damage, an increase in sperm count and viability, and general immunity. ${ }^{48}$ Lycopene has been shown to reduce lipid peroxidation. ${ }^{51,52}$ Lycopene increases sperm count. ${ }^{51,53-58}$

Daily supplementation of $4-8 \mathrm{mg}$ lycopene improves sperm motility, ${ }^{59,60}$ which was also shown in animal studies. ${ }^{56,61}$ Daily supplementation with $14 \mathrm{mg}$ lactolycopene, a combination of lycopene with whey protein, was shown to improve sperm motility and morphology in young healthy men. ${ }^{62}$ Durairajanayagam et al concluded that daily 4-8 mg lycopene supplementation for 3-12-months is sufficient to treat male infertility. ${ }^{48,59,60}$ Supplementation of $20 \mathrm{mg} / \mathrm{d}$ lycopene for 3-months prior to in vitro fertilization (IVF) treatment resulted in 7 spontaneous pregnancies prior to treatment and 15 pregnancies post treatment and a significant improvement in docosahexaenoic acid (DHA)/arachidonic acid (AA) ratio in seminal plasma. ${ }^{63}$ Twenty-five lycopene supplementation over 12-weeks in infertile men resulted in a significant increase in sperm count and concentration and a significant increase in transient aplastic crisis (TAC) (Table 1). ${ }^{58}$

\section{CARDIOVASCULAR HEALTH}

Cardiovascular disease (CVD) is the leading cause of mortality worldwide. Key risk factors include high blood pressure, high cholesterol and smoking. Damage and remodeling of blood vessels can result in blood flow restrictions affecting the heart and central nervous system in CVD, and atherosclerosis is the leading cause of CVD. ${ }^{64}$
Evidence suggests that Mediterranean countries have lower risks of CVD mortality when compared to other regions of Europe and the United States. ${ }^{65}$ This effect has been attributed to a diet rich in vegetables, including tomatoes, tomato products and olive oil. ${ }^{66,67}$ While low plasma levels of lycopene have been reported in hypertension, myocardial infarction, stroke, and atherosclerosis, ${ }^{68,69}$ dietary intake and high serum concentration of lycopene significantly reduced the risk of major cardiac events. ${ }^{70,71}$ In addition, epidemiological studies support the role of lycopene in the prevention of cardiovascular disease. ${ }^{72}$

Oxidative stress plays a significant role in cardiovascular disease ${ }^{64,73,74}$ and may be a major cause of lycopene depletion in ageing and cardiovascular disease. ${ }^{72}$ Low carotenoid levels, especially decreased serum lycopene levels, were shown to be strongly predictive of all-cause mortality and poor outcomes of CVD. ${ }^{72}$ Daily lycopene supplementation has been shown to increase serum lycopene concentration ${ }^{75-77}$ and reduce oxidative stress markers and improve antioxidant status. ${ }^{78-82}$

Anti-inflammatory mechanisms of lycopene include the decrease of adhesion molecules and pro-inflammatory cytokines, inhibition of leukocyte migration and genes involved in inflammation, impaired monocyte-endothelium interaction, $\mathrm{T}$ lymphocytes activation, synthesis of advanced glycation products (AGE) and their receptors (RAGE), and down-regulation of cyclooxygenase $2 .{ }^{83}$ Lycopene inhibited the expression of ICAM-1, TNF- $\alpha$ induced NFkB activation and interaction between monocytes and endothelial cells. ${ }^{84}$ Serum lycopene was inversely associated with VCAM-1 and LDL. ${ }^{85} \mathrm{Kim}$ et al showed lycopene supplementation improved microvascular function, measured by decreased concentrations of sVCAM and sICAM, a reduction in DNA damage, and an increase in superoxide dismutase (SOD) activity. ${ }^{86}$ Lycopene was shown to reduce the synthesis of AGE,

\begin{tabular}{|c|c|c|c|}
\hline Authors & Population & Lycopene Dose & Results \\
\hline $\begin{array}{l}\text { Abdel-Daim MM } \\
\text { et al. }{ }^{81}\end{array}$ & 56 Swiss albino mice & $10 \mathrm{mg}$, I5-days & $\begin{array}{l}\uparrow \mathrm{GSH}, \mathrm{GSH}-\mathrm{Px}, \mathrm{SOD}, \mathrm{CAT} \\
\downarrow \mathrm{Ck}-\mathrm{MB}, \mathrm{LHD}, \mathrm{CTnT}, \mathrm{NO}, \mathrm{MDA} \\
\downarrow \text { caspase-3, Bax- and CK }\end{array}$ \\
\hline Brito $A K$ et al. ${ }^{100}$ & 30 male hamsters & $\begin{array}{l}25,50 \mathrm{mg} \text { lycopene-rich } \\
\text { extract, 28-days }\end{array}$ & Significant $\downarrow$ TG, MDA-p, MDO \\
\hline Kumar R et al. ${ }^{99}$ & 24 male SD rats & $50 \mathrm{mg} / \mathrm{kg}$, 45-days & $\begin{array}{l}\text { Significant } \uparrow \text { HDL-C }(p<0.05) \\
\downarrow T C, \text { LDL-C, very LCL-C, TG }\end{array}$ \\
\hline Petyaev IM et al. ${ }^{75}$ & $\begin{array}{l}\text { I } 42 \text { human adults with } \\
\text { coronary vascular } \\
\text { disease }\end{array}$ & $\begin{array}{l}7 \text { mg either lactolycopene } \\
\text { (Lac) or lycosome- } \\
\text { formulated GA lycopene } \\
\text { (LYC), 4-weeks }\end{array}$ & $\begin{array}{l}\text { LYC } \uparrow \text { serum lycopene by } 2.9 \text { - and } 4.3 \text {-fold after } 2 \text { and } 4 \text {-weeks } \\
\text { Lac by } 0.5 \text {-fold after } 4 \text {-weeks } \\
\text { LYC significant } \uparrow F M D ~ I . I \text { points }(10.7 \%) \text { and StO2 I.9 points }(15.9 \%) \text { over baseline } \\
\text { LYC } \downarrow \operatorname{lgG}(3 \times p<0.05) \text {, ox-LDL }(5 \times p<0.05) \text { and IOD }(3 \times p<0.05)\end{array}$ \\
\hline Saracoglu G et al. ${ }^{80}$ & Wistar albino STZ rats & $4 \mathrm{mg} / \mathrm{kg}, 28$-days & $\begin{array}{l}\uparrow \mathrm{GPx}, \mathrm{SOD}, \mathrm{CAT} \\
\downarrow \mathrm{MDA}\end{array}$ \\
\hline Yilmaz S et al. $^{82}$ & $\begin{array}{l}42 \text { male Wistar albino } \\
\text { rats }\end{array}$ & $5 \mathrm{mg} / \mathrm{kg}$, I5-days & $\begin{array}{l}\uparrow \mathrm{GSH}, \mathrm{GST}, \mathrm{GSH}-\mathrm{Px}, \mathrm{SOD}, \mathrm{CAT}, \mathrm{G} 6 \mathrm{PD} \\
\downarrow \mathrm{MDA}\end{array}$ \\
\hline Zeng J et al. ${ }^{23}$ & C57/BL6J mice & $50 \mathrm{mg} / \mathrm{kg}, 5$-weeks & $\begin{array}{l}\uparrow \text { Inhibited cardiac hypertrophy and improved cardiac dysfunction } \\
\downarrow \text { ANP, BNP } \\
\downarrow \text { mitochondrial ROS, MAPKs } \\
\uparrow \text { HO-I, SODI, CAT }\end{array}$ \\
\hline Zheng $Z$ et al. ${ }^{78}$ & T2DM rats & $\begin{array}{l}0,5,10,15 \mathrm{mg} / \mathrm{kg} \\
\text { Lycopene, } 10 \text {-weeks }\end{array}$ & $\begin{array}{l}\text { Dose dependent } \downarrow \text { oxidative stress markers (GHb, ox-LDL, and MDA) and inflammatory } \\
\text { factors (TNF- } \alpha \text { and CRP) } \\
\uparrow \text { TAC (CAT, SOD, and GPx) }\end{array}$ \\
\hline
\end{tabular}


down regulating their receptors (RAGE) which contributes to vessel protection. ${ }^{87,88}$ Lycopene reduced inflammatory markers in various animal models. ${ }^{78,81,89}$

Lycopene improves endothelial function by increasing the bioavailability of nitric oxide (NO), improving endotheliumdependent vasodilation, reducing protein, lipids, DNA and mitochondrial damage and increasing antioxidant potential. ${ }^{81,83,86,90-94}$ Lycopene supplementation reduced DNA damage, ${ }^{93}$ up-regulated mitochondrial gene expression ${ }^{89}$ and reduced mitochondrial oxidation. ${ }^{23}$ Foot-and-mouth disease (FMD) was significantly increased by 1.1 points $(10.9 \%)$ with 4-weeks lycopene supplementation in adults with coronary vascular disease. ${ }^{75}$ Blood pressure was reduced with lycopene supplementation in individuals with stage 1 hypertension, ${ }^{95,96}$ who were otherwise healthy. ${ }^{86}$

Lycopene impacts blood lipids, where a dose-dependent reduction in intracellular cholesterol was seen in human studies, and lycopene and tomato products decreased plasma total cholesterol, low-density lipoprotein (LDL) cholesterol and increased high-density lipoprotein (HDL) cholesterol in animal models. ${ }^{97}$ Lycopene supplementation reduced cholesterol and LDL in healthy postmenopausal women. ${ }^{98}$ Significant increase in HDL and decrease in total cholesterol (TC), LDL and triglyceride (TG) were observed in lycopene-supplemented rats, ${ }^{99}$ significant decrease in TG in lycopene supplemented hamsters ${ }^{100}$ and a reduction in oxidized LDL in lycopene-supplemented humans ${ }^{75}$ and lycopene-supplemented rats. ${ }^{78}$

Intima media thickness (IMT) is an established index of the structural change of an artery ${ }^{101}$ and IMT, especially that of the carotid, is associated with the presence of cardiovascular risk factors. ${ }^{102,103}$ Serum carotenoid and lycopene levels are inversely associated with intima-media thickness. ${ }^{104-107}$ Lycopene and lutein supplementation (20 $\mathrm{mg}$ each)resulted in a decrease in IMT after 12 -months, where the combination proved more effective com- pared to lutein alone (Table 2). ${ }^{107}$

\section{LIVER HEALTH}

The liver is the largest visceral organ in the abdominal cavity and largest gland in the body, weighting about $1.5 \mathrm{~kg}$ in a healthy adult. The liver plays a major role in metabolism, including the production of certain proteins, cholesterol and the conversion of excess glucose to glycogen, and is involved in over 500 vital functions such as drug detoxification, the production of bile and the synthesis of steroid hormones. ${ }^{108-110}$ Non-alcoholic fatty liver disease (NAFLD), the most common form of liver disease, refers to a group of conditions resulting in excess fat in the liver(hepatic steatosis) of people who drink little or no alcohol and involves the development of insulin resistance, lipid peroxidation, oxidative stress and inflammation. ${ }^{108,110,111}$ Global and US prevalence of NAFLD are both estimated at $24 \% .^{112}$

As potent antioxidants and anti-inflammatory agents, carotenoids can play a role in protecting the liver against oxidative stress, insulin resistance and inflammation. ${ }^{111,113-116}$ In a prospective study of Chinese adults aged 40-75-years, higher serum carotenoid concentrations were positively associated with NAFLD improvements, specifically in lowering serum RBP4, triglycerides, homeostasis model assessment-insulin resistance (HOMA-IR), and body mass index (BMI). ${ }^{114}$ Lycopene is one of the most studied carotenoids regarding NAFLD ${ }^{117}$ due to multiple mechanisms beyond its antioxidant capacity, such as regulation of gene expression and gap junctions, antiproliferative capacity, lipid peroxidation and immune and hormonal modulation. . $^{27,118,119}$

Numerous animal models demonstrated a reduction in hepatic steatosis, ${ }^{119-121}$ reduced hepatic inflammation ${ }^{116,120,123-127}$ reduced lipid peroxidation ${ }^{123,127,128}$ and antioxidant protection. ${ }^{116,120,125,127-131}$ In a study with Sprague-Dawley rats, lycopene and tomato extract resulted in a significant decrease in cyto-

\begin{tabular}{|c|c|c|c|}
\hline Authors & Population & $\begin{array}{l}\text { Lycopene Dose, } \\
\text { Duration }\end{array}$ & Results \\
\hline $\begin{array}{l}\text { Bandeira ACB et } \\
\text { al. } 116\end{array}$ & $40 \mathrm{C} 57 \mathrm{BL} / 6$ male mice & $10 \mathrm{mg} / \mathrm{kg}, 14$-days & $\begin{array}{l}\text { Improve redox state and antioxidant activity } \\
\downarrow \text { IL-I } \beta, \text { MMP-2 } \\
\uparrow \text { CAT, GSH }\end{array}$ \\
\hline Karaca $A$ et al. ${ }^{131}$ & Rats & $5 \mathrm{mg} / \mathrm{kg}$, 15 -days & $\begin{array}{l}\text { Significantly } \downarrow \text { MDA, aspartate transaminase, alanine transaminase, lactate dehydrogenase } \\
\uparrow \text { glutathione, antioxidant enzymes }\end{array}$ \\
\hline Li C-C et al. ${ }^{127}$ & $\begin{array}{l}\text { I8 BCOI-/-/BCO2-/- } \\
\text { double knockout mice }\end{array}$ & $\begin{array}{l}2.3 \mathrm{mg} / \mathrm{g} \text { from tomato } \\
\text { powder, } 24 \text {-weeks }\end{array}$ & $\begin{array}{l}\downarrow \text { Severity of hepatic steatosis } \\
\uparrow \text { SIRTI } \\
\text { Significantly } \uparrow \text { lipogenesis (p-AMPK and p-ACC) } \\
\uparrow \text { fatty acid oxidation ( } \uparrow P P A R \alpha, \text { cpt I, acox I and } \downarrow \text { cd } 36 \text {, dgat I) } \\
\downarrow \text { inflammation (TNF- } \alpha \text {, il- } \mid \beta, \text { il-6) }\end{array}$ \\
\hline Sadek K et al. ${ }^{128}$ & 40 male albino rats & $10 \mathrm{mg} / \mathrm{kg}, 15$-days & $\begin{array}{l}\downarrow \text { Fatty acid degeneration, lipid peroxidation and liver necrosis } \\
\uparrow \text { Antioxidant activity } \\
\downarrow \text { DNA fragmentation, apoptosis }\end{array}$ \\
\hline Shimizu Y et al. ${ }^{126}$ & $\mathrm{BALB} / \mathrm{c}$ male mice & $25 \mathrm{mg} / \mathrm{kg}$, single dose & $\begin{array}{l}\text { Significant } \downarrow \text { proinflammatory cytokines (AST, ALT, IL- } 6, \text { IFN- } \gamma, \text { TNF- } \alpha \text { ) } \\
\uparrow \text { Cell viability and growth }\end{array}$ \\
\hline Wang J et al. ${ }^{125}$ & 30 male $\mathrm{C} 57 \mathrm{BI} / 6 \mathrm{~J}$ mice & $\begin{array}{l}0.03 \% \text { lycopene w/w } \\
\text { mixed into normal } \\
\text { chow, } 5 \text {-weeks }\end{array}$ & $\begin{array}{l}\downarrow \text { LPS-induced insulin resistance and mitochondrial dysfunction } \\
\downarrow \text { Neuro and hepatic inflammation } \\
\downarrow \text { Circulating insulin and proinflammatory mediators ((TNF- } \alpha \text {, il- } \mid \beta, \text { il-6) }\end{array}$ \\
\hline Yin Y et al. ${ }^{79}$ & $\begin{array}{l}\text { T2DM Srague Dawley } \\
\text { rats }\end{array}$ & $\begin{array}{l}\text { I0,20 mg lycopene, } \\
\text { I0-weeks }\end{array}$ & $\downarrow M D A$ and $\uparrow S O D$ and GSH-Px in pancreatic tissue \\
\hline
\end{tabular}


chrome P450 2E1, inflammatory foci, and mRNA expression of proinflammatory cytokines (TNF- $\alpha$, IL-1 $\beta$, and IL-12). ${ }^{123}$ Lycopene altered the down regulation of the expression of messenger RNA-21 (mRNA-21) in mice. ${ }^{122}$ Tomato powder which contained $218.6 \mathrm{mg} / \mathrm{g}$ lycopene was shown to protect the liver against oxidative stress, fatty infiltration and necrosis caused by thermally oxidized tallow in a rat model. ${ }^{132}$ In a tramadol-induced hepatotoxicity rat model, lycopene reduced fatty acid degeneration and necrosis, and lipid peroxidation, inhibited DNA fragmentation and apoptosis signaling, and increased antioxidant activity. ${ }^{128}$ Piña-Zentella et al demonstrated protective effects of lycopene against NAFLD in rats. ${ }^{133}$ Wang et al showed 5 weeks supplementation of $0.03 \% \mathrm{w} / \mathrm{w}$ lycopene added to chow ameliorated lipopolysaccharide (LPS)-induced insulin resistance and mitochondrial dysfunction in the mouse brain and liver. ${ }^{125}$ In a BCO1-/-/BCO2-/- double knockout mouse model, Li et al demonstrated 24-weeks of supplementation of $2.3 \mathrm{mg}$ lycopene from tomato powder reduced the severity of hepatic steatosis, increased SIRT1, significantly increased lipogenesis and fatty acid oxidation, and reduced inflammation. ${ }^{127}$ Lycopene improved redox imbalance, increased antioxidant enzymes, and decreased inflammation, attenuating the effects of APAP-induced liver injury in mice (Tabel 3). ${ }^{116}$

\section{SKIN HEALTH |}

The skin is the largest organ of the body, accounting for approximately $15 \%$ of total body weight. The skin protects against external physical, chemical, and biological assailants, prevents excess water loss from the body, and regulates body temperature. ${ }^{134} \mathrm{Pho}-$ toaging is a result of chronic DNA photo damage, lipid peroxidation, and protein cross-linking from ultraviolet (UV)-generated ROS, which leads to premature wrinkling and pigmentary changes, and photo-induced skin cancer. Photoaging can be prevented by sun avoidance or the use of sunscreens, retinoids for collagen support and antioxidants to neutralize free radicals. ${ }^{118,135-138}$

Carotenoids accumulate in the skin and can protect against UV-generated ROS. ${ }^{139,140}$ Multiple factors impact their skin concentration. Dietary supplementation can increase skin carotenoid concentration, and oxidative stress, for example from cigarette smoking or exposure to UV-rays, can decrease their concentration. ${ }^{141}$ Lycopene skin and plasma concentration was shown to be comparable or higher than that of $\beta$-carotene. ${ }^{142}$ Lycopene supplementation increases both skin and plasma lycopene concentration, ${ }^{75,76}$ and a correlation between lycopene skin and plasma concentration has been demonstrated. ${ }^{75,76,143}$ Ribaya-Mercado et al found Lycopene to be the most quickly depleted antioxidant in skin upon solar radiation exposure, and suggest lycopene plays a role in mitigating photo-oxidative damage in tissues through protection against UV-radiation. ${ }^{142}$ A significant correlation between skin roughness and lycopene skin concentration has been seen. ${ }^{144}$

Consumption of lycopene and lycopene-rich products protects the skin against sunburn by increasing the basal defense against UV light-mediated damage. ${ }^{119}$ Studies have demonstrated supplementation with lycopene or lycopene-rich products, orlycopene mixed with other carotenoids or antioxidants reduce UV-induced erythema and increase minimal erythema dose (MED) ${ }^{77,145-148}$ Forty percent $(40 \%)$ reduction in erythema resulted after 10 weeks daily consumption of $40 \mathrm{~g}$ tomato paste, equivalent to $16 \mathrm{mg}$ lycopene. ${ }^{145}$ Twelve weeks daily supplementation of $8 \mathrm{mg}$ each of lycopene, lutein and $\beta$-caroteneameliorates UVinduced erythema. ${ }^{147}$ An increase in MED and reduction in UVinduced erythema was observed after 7-weeks daily supplementation of an antioxidant complex including lycopene, $\beta$-carotene, $\alpha$-tocopherol and selenium. ${ }^{146}$ Lycopene-enriched tomato extract suppressed skin tumorigenesis in BALB/c mice, inhibited cell proliferation, decreased expression of angiogenic genes and increased expression of transmembrane proteins. ${ }^{149}$

Lycopene protects the skin against photoaging by its antioxidative capacity, anti-inflammatory effects, impact on gene expression, and protection against lipid peroxidation. ${ }^{139,140,150-152}$

\begin{tabular}{|c|c|c|c|}
\hline Authors & Population & Lycopene Dose, Duration & Results \\
\hline $\begin{array}{l}\text { Grether-Beck S } \\
\text { et al. }{ }^{152}\end{array}$ & $\begin{array}{l}65 \text { healthy human } \\
\text { adults }\end{array}$ & $10 \mathrm{mg}$ daily, 12 weeks & Inhibited mRNA expression of HO-I, MMP-I and ICAM-I \\
\hline Groten $\mathrm{K}$ et al. ${ }^{77}$ & $\begin{array}{l}\text { I } 49 \text { healthy human } \\
\text { adults }\end{array}$ & $\begin{array}{l}15 \mathrm{mg} \text { lycopene, } 5.8 \mathrm{mg} \\
\text { phytoene and phytofluene, } \\
0.8 \mathrm{mg} \text { beta-carotene, } 5.6 \mathrm{mg} \\
\text { tocopherols from tomato } \\
\text { extract and } 4 \mathrm{~m} \text { carnosic acid } \\
\text { from rosemary or placebo }\end{array}$ & $\begin{array}{l}\text { Protected against UVB-induced erythema } \\
\text { Significantly } \downarrow \text { UVB-induced IL6 and TNF } \alpha \\
\uparrow \text { plasma carotenoid levels }\end{array}$ \\
\hline Koul A et al. ${ }^{149}$ & $60 \mathrm{male} \mathrm{Balb/c} \mathrm{mice}$ & $\begin{array}{l}5 \mathrm{mg} / \mathrm{kg} \text { bw lycopene-en- } \\
\text { riched tomato extract }\end{array}$ & 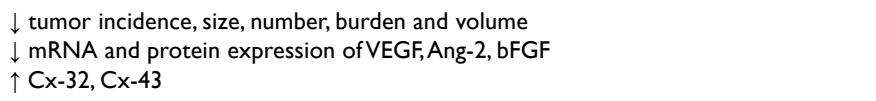 \\
\hline Petaev I et al. ${ }^{75}$ & $\begin{array}{l}32 \text { healthy human } \\
\text { adults }\end{array}$ & $7 \mathrm{mg}$ daily, 4 weeks & $\begin{array}{l}\text { Significant } \uparrow \text { serum concentration } 2.6 \& 3.4 \times \text { over control after } 2 \& 4 \text { wks, respectively } \\
\text { Stepwise } \uparrow \text { in IF staining of skin corneocytes and sebum }\end{array}$ \\
\hline Petaev I et al. ${ }^{76}$ & $\begin{array}{l}\text { I } 20 \text { healthy human } \\
\text { adults; subgroup for } \\
\text { supplementation } 15 \\
\text { healthy human adults }\end{array}$ & $7 \mathrm{mg}$ daily, 4 weeks & $\begin{array}{l}\uparrow \text { Skin and serum lycopene concentration } \\
\text { Significant } \uparrow \text { in desquamated corneocytes lycopene concentration during whole } \\
\text { supplementation period } \\
\uparrow \text { in sebum lycopene concentration during first } 2 \text { weeks of supplementation }\end{array}$ \\
\hline
\end{tabular}


Supplementation with lycopene-rich TNC and lutein-containing capsules resulted in a significant reduction of UV-induced mRNA expression of HO-1, MMP-1 and ICAM-1. ${ }^{139}$ Lycopene, $\beta$-carotene, $\alpha$-tocopherol, and selenium supplementation showed a reduction of UV-induced $\mathrm{p} 53$ expression, sun burn cells (SBCs) and lipoperoxide levels. ${ }^{146}$ Lycopene from tomato extract protected against upregulation of proinflammatory cytokines. ${ }^{77}$ Supplementation of a lycopene, $\beta$-carotene and antioxidant combination inhibited the expression of matrix metalloproteinase (Table 4). ${ }^{148}$

\section{CONCLUSION}

Lycopene, one of the six most predominant carotenoids found in the human diet and plasma, is the most potent singlet oxygen quenching carotenoid and a strong anti-inflammatory agent. Aging and major health problems today deal with the accumulation of ROS, including inflammation and irregular lipid metabolism. Due to its antioxidative and anti-inflammatory effects, and other mechanisms demonstrated in the research, for example lipid metabolism and cellular communication and differentiation,lycopene can play a protective role in aging and be a key component in strategies totackle lifestyle metabolic and chronic health issues.

\section{REFERENCES}

1. Britton G, Liaaen-Jensen S, Pfander H. Carotenoids: Handbook. Basel, Switzerland: Birkhäuser Basel; 2004.

2. Yabuzaki J. Carotenoids database: Structures, chemical fingerprints and distribution among organisms. Database (Oxford). 2017; 2017: bax004. doi: 10.1093/database/bax004

3. Nguyen ML, Schwartz SJ. Lycopene: Chemical and biological properties. Food Technol. 1999; 53(1): 38-45.

4. Aoki H, Kieu NT, Kuze N, Tomisaka K, Van Chuyen N. Carotenoid pigments in GAC fruit (Momordica cochinchinensis SPRENG). Biosci Biotechnol Biochem. 2002; 66(11): 2479-2482. doi: 10.1271/bbb.66.2479

5. Rao AV, Ray MR, Rao LG. Lycopene. Adv Food Nutr Res. 2006; 51: 99-164. doi: 10.1016/S1043-4526(06)51002-2

6. Clinton SK. Lycopene Chemistry, biology, and implications for human disease. Nutr Rev. 1998; 56: 35-51. doi: 10.1111/j.17534887.1998.tb01691.x

7. Bohm F, Edge R, Burke M, Truscott TG. Dietary uptake of lycopene protects human cells from singlet oxygen and nitrogen dioxide-ROS components from cigarette smoke. J Photochem Photobiol B. 2001; 64(2-3): 176-178. doi: 10.1016/s1011-1344(01)00221-4

8. Wang XD. Lycopene metabolism and its biological significance. Am J Clin Nutr. 2012; 96(5): 1214S-1222S. doi: 10.3945/ ajcn.111.032359

9. Wang XD. Carotenoids. In: Ross CA, Caballero B, Cousins RJ, Tucker KL, Ziegler TR, eds. Modern Nutrition in Health and Dis- ease. 11th ed. Pennsylvania, USA: Lippincott Williams \& Wilkins; 2014: 427-439.

10. Unlu NZ, Bohn T, Francis DM, Nagaraja HN, Clinton SK, Schwartz SJ. Lycopene from heat-induced cis-isomer-rich tomato sauce is more bioavailable than from all-trans-rich tomato sauce in human subjects. Br J Nutr. 2007; 98(1): 140-146. doi: 10.1017/ S0007114507685201

11. Castenmiller JJ, West CE, Linssen JP, Van Het Hof KH, Voragen AG. The food matrix of spinach is a limiting factor in determining the bioavailability of $\beta$-carotene and to a lesser extent of lutein in humans. J Nutr. 1999; 129(1): 349-355. doi: 10.1093/ in/129.2.349

12. Williams AW, Boileau TWM, Erdman JW Jr. Factors influencing the uptake and absorption of carotenoids. Proc Soc Exp Biol Med. 1998; 218(2): 106-108. doi: 10.3181/00379727-218-44275

13. Cooperstone JL, Ralston RA, Riedl KM, et al. Enhanced bioavailability of lycopene when consumed as cis-isomers from tangerine compared to red tomato juice, a randomized, crossover clinical trial. Mol Nutr Food Res. 2015; 59(4): 658-669. doi: 10.1002/mnfr.201400658

14. Unlu, NZ; Bohn, T; Clinton, SK; Schwartz, SJ. Carotenoid absorption from salad and salsa by humans is enhanced by the addition of avocado or avocado oil. J Nutr. 2005; 135(3): 431-436. doi: $10.1093 /$ jn/135.3.431

15. Stahl W, Sies H. Lycopene: a biologically important carotenoid for human? Arch Biochem Biophys. 1996; 336: 1-9. doi: 10.1006/ abbi. 1996.0525

16. Gajowik A, Dobrzyńska M. Lycopene - Antioxidant with radioprotective and anticancer properties. A review. Rocz Panstw Zakel Hig. 2014; 65(4): 263-271.

17. Khachik F, Carvalho L, Bernstein PS, Muir GJ, Zhao DY, Katz NB. Chemistry, distribution, and metabolism of tomato carotenoids and their impact on human health. Exp Biol Med (Maywood). 2002; 227(10): 845-851. doi: 10.1177/153537020222701002

18. Miller NJ, Sampson J, Candeias LP, Bramley PM, Rice-Evans CA. Antioxidant activities of carotenes and xanthophylls. FEBS Lett. 1996; 384(3): 240-242. doi: 10.1016/0014-5793(96)00323-7

19. Mortensen A, Skibsted LH. Relative stability of carotenoid radical cations and homologue tocopheroxyl radicals. A real time kinetic study of antioxidant hierarchy. FEBS Lett. 1997; 417(3): 261-216. doi: 10.1016/s0014-5793(97)01297-0

20. Tambunan RZ, Rusmarilin H, Kaban J. Antioxidant activity of tomato juice rich in lycopene antioxidant as degenerative chemopreventive agents using citrus aurantifolia juice as a preservative. IOP Conf Ser Earth Environ Sci. 2018; 205(1): 12. doi: 10.1088/1755-1315/205/1/012035 
21. Kim $\mathrm{CH}$ et al. Antioxidant capacity and anti-inflammatory activity of lycopene in watermelon. Int J Food Sci Tech. 2014; 49(9): 2083-2091. doi: 10.1111/ijfs.12517

22. Tvrdá E, Kováčik A, Tušimová E, et al. Antioxidant efficiency of lycopene on oxidative stress - induced damage in bovine spermatozoa. J Anim Sci Biotechnol. 2016; 7(1): 50. doi: 10.1186/ s40104-016-0113-9

23. Zeng J, Zhao J, Dong B, et al. Lycopene protects against pressure overload-induced cardiac hypertrophy by attenuating oxidative stress. J Nutr Biochem. 2019; 66: 70-78. doi: 10.1016/j. jnutbio.2019.01.002

24. Cho E, Seddon JM, Rosner B, Willett WC, Hankinson SE. Prospective study of intake of fruits, vegetables, vitamins, and carotenoids and risk of age-related maculopathy. Arch Ophthalmol. 2004; 122(6): 883-892. doi: 10.1001/archopht.122.6.883

25. Stahl W, Junghans A, de Boer B, Driomina E, Briviba K, Sies H. Carotenoid mixtures protect multilamellar liposomes against oxidative damage: Synergistic effects of lycopene and lutein. FEBS Lett. 1998; 427(2): 305-308. doi: 10.1016/s0014-5793(98)00434-7

26. Di Mascio P, Kaiser S, Sies H. Lycopene as the most effective biological carotenoid singlet oxygen quencher. Arch Biochem Biophys. 1989; 274: 532-538. doi: 10.1016/0003-9861(89)90467-0

27. Rao AV, Rao LG. Carotenoids and human health. Pharmacol Res. 2007; 55(3): 207-216. doi: 10.1016/j.phrs.2007.01.012

28. Palozza P, Catalano A, Simone R, Cittadini A. Lycopene as a guardian of redox signalling. Acta Biochim Pol. 2012; 59: 21-25. doi: 10.18388/abp.2012_2163

29. Rawla P. Epidemiology of prostate cancer. World J Oncol. 2019; 10(2): 63-89. doi: 10.14740/wjon1191

30. Centers for Disease Control and Prevention (CDC). Prostate Cancer Statistics. Web site. https://www.cdc.gov/cancer/prostate/statistics/index.htm. Accessed November 19, 2019.

31. National Cancer Institute. Cancer Stat Facts: Prostate Cancer. Web site. https://seer.cancer.gov/statfacts/html/prost.html. Accessed November 19, 2019.

32. Miller EC, Hadley CW, Schwartz SJ, Erdman JW Jr, Boileau TW, Clinton SK. Lycopene, tomato products, and prostate cancer prevention. Have we established causality? Pure Appl Chem. 2002; 74(8): 1435-1441. doi: 10.1351/pac200274081435

33. Etminan M, Takkouche B, Caamaño-Isorna F. The role of tomato products and lycopene in the prevention of prostate cancer: a meta-analysis of observational studies. Cancer Epidemiol Biomarkers Prev. 2004; 13(3): 340-345.

34. Chen P, Zhang W, Wang X, et al. Lycopene and risk of pros- tate cancer. A systematic review and meta-analysis. Medicine (Baltimore). 2015; 94(33): e1260. doi: 10.1097/MD.0000000000001260

35. Wang Y, Cui R, Xiao Y, Fang J, Xu Q. Effect of carotene and lycopene on the risk of prostate cancer: A systematic review and dose-response meta-analysis of observational studies. PLoS One. 2015; 10(9): e0137427. doi: 10.1371/journal.pone.0137427

36. Lane JA, Er V, Avery KNL, et al. ProDiet: A Phase II randomized placebo-controlled trial of green tea catechins and lycopene in men at increased risk of prostate cancer. Cancer Prev Res (Phila). 2018; 11(11): 687-696. doi: 10.1158/1940-6207.CAPR-180147

37. Beynon RA, Richmond RC, Santos Ferreira DL, et al. Investigating the effects of lycopene and green tea on the metabolome of men at risk of prostate cancer: The ProDiet randomised controlled trial. Int J Cancer. 2019; 144(8): 1918-1928. doi: 10.1002/ ijc.31929

38. Khandrika L, Kumar B, Koul S, Maroni P, Koul HK. Role of oxidative stress in prostate cancer. Cancer Lett. 2009; 282(2): 125 136. doi: $10.1016 /$ j.canlet.2008.12.011

39. Zhang LX, Cooney RV, Bertram JS. Carotenoids upregulate conexin 43 gene expression independent of their provitamin A or antioxidant properties. Cancer Res. 1992; 52: 5707-5712.

40. Bankson DD, Countryman CJ, Collins SJ. Potentiation of the retinoic acid-induced differentiation of HL-60 cells by lycopene. Am J Clin Nutr. 1991; 53(Suppl): 13-17.

41. Matsushima-Nishiwaki R, Shidoji Y, Nishiwaki S, Yamada T, Moriwaki H, Muto Y. Suppression by carotenoids of microcystin-induced morphological changes in mouse hepatocytes. Lipids. 1995; 30(4): 1029-1034. doi: 10.1007/bf02536288

42. Pastori M, Pfander H, Boscoboinik D, Azzi A. Lycopene in association with $\alpha$-tocopherol inhibits at physiological concentrations proliferation of prostate cancer cells. Biochem Biophys Res Comm. 1998; 250(4): 582-585. doi: 10.1006/bbrc.1998.9351

43. Yang CM, Lu YL, Chen HY, Hu ML. Lycopene and the LXRalpha agonist T0901317 synergistically inhibit the proliferation of androgen-independent PCa cells via the PPARgamma-LXRalpha-ABCA1 pathway. J Nutr Biochem. 2012; 23: 1155-1162. doi: 10.1016/j.jnutbio.2011.06.009

44. Rafi MM, Kanakasabai S, Reyes MD, Bright JJ. Lycopene modulates growth and survival associated genes in PCa. J Nutr Biochem. 2013; 24(10): 1724-1734. doi: 10.1016/j.jnutbio.2013.03.001

45. Jiang LN, Liu YB, Li BH. Lycopene exerts anti-inflammatory effect to inhibit prostate cancer progression. Asian J Androl. 2019; 21(1): 80-85. doi: 10.4103/aja.aja_70_18

46. Fainberg, J and Kashanian, A. Recent advances in understand- 
ing and managing male infertility. F1000Res. 2019; 8. F1000 Faculty Rev-670. doi: 10.12688/f1000research.17076.1

47. Aitken J, Fisher H. Reactive oxygen species generation and human spermatozoa: The balance of benefit and risk. Bioessays. 1994; 16(4): 259-267. doi: 10.1002/bies.950160409

48. Durairajanayagam D, Agarwal A, Ong C, Prashast P. Lycopene and male infertility. Asian I Androl. 2014; 16(3): 420-425. doi: 10.4103/1008-682X.126384

49. Palan P, Naz R. Changes in various antioxidant levels in human seminal plasma related to immunoinfertility. Arch Androl. 1996; 36: 139-143. doi: 10.3109/01485019608987090

50. Goyal A, Chopra M, Lwaleed BA, Birch B, Cooper AJ. The effects of dietary lycopene supplementation on human seminal plasma. BJU Int. 2007; 99: 1456-1460. doi: 10.1111/j.1464410X.2007.06804.x

51. Aly HA, El-Beshbishy HA, Banjar ZM. Mitochondrial dysfunction induced impairment of spermatogenesis in LPS-treated rats: Modulatory role of lycopene. Eur J Pharmacol. 2012; 677: 3138. doi: 10.1016/j.ejphar.2011.12.027

52. Sarkar PD, Gupt T, Sahu A. Comparative analysis of lycopene in oxidative stress. J Assoc Physicians India. 2012; 60: 17-19.

53. Mangiagalli MG, Martino PA, Smajlovic T, GuidobonoCavalchini L, Marelli SP. Effect of lycopene on semen quality, fertility and native immunity of broiler breeder. Br Poult Sci. 2010; 51: 152-157. doi: 10.1080/00071660903401540

54. Mangiagalli MG, Cesari V, Cerolini S, Luzi F, Toschi I. Effect of lycopene supplementation on semen quality and reproductive performance in rabbit. World Rabbit Sci. 2012; 20: 141-148. doi: $10.4995 /$ wrs. 2012.1150

55. Aitken RJ, Irvine DS, Wu FC. Prospective analysis of sperm-oocyte fusion and reactive oxygen species generation as criteria for the diagnosis of infertility. Am J Obstet Gynecol. 1991; 164: 542-551. doi: 10.1016/s0002-9378(11)80017-7

56. Aly H. Testicular toxicity of gentamicin in adult rats: Ameliorative effect of lycopene. Hum Exp Toxicol. 2019; 38(11): 13021313. doi: $10.1177 / 0960327119864160$

57. Tripathy A, Ghosh A, Dey A, Pakhira BP, Ghosh D. Attenuation of the cyproterone acetate-induced testicular hypofunction by a novel nutraceutical lycopene: A genomic approach. Andrologia. 2017; 49(8). doi: 10.1111/and.12709

58. Nouri M, Amani R, Nasr-Esfahani M, Tarrahi MJ. The effects of lycopene supplement on the spermatogram and seminal oxidative stress in infertile men: A randomized, double-blind, placebo-controlled clinical trial. Phytother Res. 2019; 33(12): 3203-3211. doi: $10.1002 /$ ptr.6493
59. Mohanty N, Kumar S, Jha AK, Arora RP. Management of idiopathic oligoasthenospermia with lycopene. Indian J Urol. 2001; 18: 57-61.

60. Gupta NP, Kumar R. Lycopene therapy in idiopathic male infertility--a preliminary report. Int Urol Nephrol. 2002; 34: 369-372. doi: 10.1023/a:1024483520560

61. Hekimoglu A, Kurcer Z, Aral F, Baba F, Sahna E, Atessahin A. Lycopene, an antioxidant carotenoid, attenuates testicular injury caused by ischemia/reperfusion in rats. Tohoku J Exp Med. 2009; 218(2): 141-147. doi: 10.1620/tjem.218.141

62. Williams EA, Parker M, Robinson A, Pitt S, Pacey AA. A randomized placebo-controlled trial to investigate the effect of lactolycopene on semen quality in healthy males. Eur J Nutr. 2019. doi: 10.1007/s00394-019-02091-5

63. Filipcikova R, Oborna I, Brezinova J, et al. Lycopene improves the distorted ratio between $\mathrm{AA} / \mathrm{DHA}$ in the seminal plasma of infertile males and increases the likelihood of successful pregnancy. Biomed Pap Med Fac Univ Palacky Olomouc Czech Repub. 2015; 159(1): 77-82. doi: 10.5507/bp.2013.007

64. Gracia KC, Llanas-Cornejo D, Husi H. CVD and oxidative stress. J Clin Med. 2017; 6(2): 22. doi: 10.3390/jcm6020022

65. García-Fernández E, Rico-Cabanas L, Rosgaard N, Estruch R, Bach-Faig A. Mediterranean diet and cardiodiabesity: A review. Nutrients. 2014; 6(9): 3474-3500. doi: 10.3390/nu6093474

66. Müller-Nordhorn J, Binting S, Roll S, Willich SN. An update on regional variation in cardiovascular mortality within Europe. Eur Heart J. 2008; 29: 1316-1326. doi: 10.1093/eurheartj/ehm604

67. Krasinska B, Osińska A, Osinski M, et al. Standardised tomato extract as an alternative to acetylsalicylic acid in patients with primary hypertension and high cardiovascular risk - a randomized, controlled trial. Arch Med Sci. 2018; 14(4): 773-780. doi: 10.5114/ aoms.2017.69864

68. Wolak T, Paran E. Can carotenoids attenuate vascular aging? Vasc Pharmacol. 2013; 59(3-4): 63-66. doi: 10.1016/j. vph.2013.07.006

69. Riccioni G, D'Orazio N, Palumbo N, et al. Relationship between plasma antioxidant concentrations and carotid intima-media thickness: The asymptomatic carotid atherosclerotic disease in Manfredonia study. Eur J Cardiovasc Prev Cardiol. 2009; 16(3): 351-357. doi: 10.1097/HJR.0b013e328325d807

70. Cheng HM, Koutsidis G, Lodge JK, Ashor AW, Siervo M, Lara J. Lycopene and tomato and risk of cardiovascular diseases: a systematic review and meta-analysis of epiedemiological evidence. Crit Rev Food Sci Nutr. 2019; 59(1): 141-158. doi: 10.1080/10408398.2017.1362630 
71. Song B, Liu K, Gao Y, et al. Lycopene and risk of cardiovascular diseases: A meta-analysis of observational studies. Mol Nutr Food Res. 2017; 61(9). doi: 10.1002/mnfr.201601009

72. Petyaev IM. Lycopene deficiency in ageing and cardiovascular disease. Oxid Med Cell Longev. 2016; 3218605. doi: $10.1155 / 2016 / 3218605$

73. Dhalla NS, Temsah RM, Netticadan T. Role of oxidative stress in cardiovascular diseases. J Hypertens. 2000; 18(6): 655-673. doi: 10.1097/00004872-200018060-00002

74. Senoner T, Dichtl W. Oxidative stress in cardiovascular diseases: Still a therapeutic target? Nutrients. 2019; 11(9). doi: 10.3390/ nu11092090

75. Petyaev IM, Zigangirova NA, Pristensky D, et al. Non-invasive immunofluorescence assessment of lycopene supplementation status in skin smears. Monoclon Antib Immunodiagn Immunother. 2018; 37(3). 139-146. doi: 10.1089/mab.2018.0012

76. Petyaev IM, Pristensky DV, Morgunova EY, et al. Lycopene presence in facial skin corneocytes and sebum and its association with circulating lycopene isomer profile: Effects of age and dietary supplementation. Food Sci Nutr. 2019; 7(4): 1157-1165. doi: $10.1002 /$ fsn 3.799

77. Groten K, Marini A, Grether-Beck S, et al. Tomato phytonutrients balance UV response: Results from a double-blind, randomized, placebo-controlled study. Skin Pharmacol Physiol. 2019; 32: 101-108. doi: 10.1159/000497104

78. Zheng Z, Yin Y, Lu R, Jiang Z. Lycopene ameliorated oxidative stress and inflammation in type 2 diabetic rats. J Food Sci. 2019; 84(5): 1194-1200. doi: 10.1111/1750-3841.14505

79. Yin Y, Zheng Z, Jiang Z. Effects of lycopene on metabolism of glycolipid in type 2 diabetic rats. Biomed Pharmacother. 2019; 109: 2070-2077. doi: 10.1016/j.biopha.2018.07.100

80. Saracoğlu G, Baş H, Pandır D. Furan-induced cardiotoxicity in diabetic rats and protective role of lycopene. J Food Biochem. 2019; 43(3): e12738. doi: 10.1111/jfbc.12738

81. Abdel-Daim MM, Eltaysh R, Hassan A, Mousa SA. Lycopene attenuates tulathromycin and diclofenac sodium-induced cardiotoxicity in mice. Int J Mol Sci. 2018; 19(2). pii: E344. doi: 10.3390/ ijms19020344

82. Yilmaz S, Kaya E, Karaca A, Karatas O. Aflatoxin B1 induced renal and cardiac damage in rats: Protective effect of lycopene. Res Vet Sci. 2018; 119: 268-275. doi: 10.1016/j.rvsc.2018.07.007

83. Mozos I, Stoian D, Caraba A, Malainer C, Horbańczuk JO, Atanasov AG. Lycopene and Vascular Health. Front Pharmacol. 2018; 9: 521. doi: 10.3389/fphar.2018.00521

84. Hung CF, Huang TF, Chen BH, Shieh JM, Wu PH, Wu WB.
Lycopene inhibits TNF-alpha-induced endothelial ICAM-1 expression and monocyte-endothelial adhesion. Eur J Pharmacol. 2008; 586(1-3): 275-282. doi: 10.1016/j.ejphar.2008.03.001

85. Xu XR, Zou ZY, Huang YM, Xiao X, Ma L, Lin XM. Serum carotenoids in relation to risk factors for development of atherosclerosis. Clin Biochem. 2012; 45(16-17): 1357-1361. doi: 10.1016/j. clinbiochem.2012.07.101

86. Kim JY, Paik JK, Kim OY, Park HW, Lee JH, Jang Y. Effects of lycopene supplementation on oxidative stress and markers of endothelial function in healthy men. Atherosclerosis. 2011; 215: 189-195. doi: 10.1016/j.atherosclerosis.2010.11.036

87. Tabrez S, Al-Shali KZ, Ahmad S. Lycopene powers the inhibition of glycation-induced diabetic nephropathy: A novel approach to halt the AGE-RAGE axis menace. Biofactors. 2015; 41(5): 372-381. doi: 10.1002/biof.1238

88. Thies F, Mills LM, Moir S, Masson LF. Cardiovascular benefits of lycopene: Fantasy or reality? Proc Nutr Soc. 2017; 76(2): 122 129. doi: $10.1017 /$ S0029665116000744

89. Wang J, Zou Q, Suo YH, et al. Lycopene ameliorates systemic inflammation-induced synaptic dysfunction via improving insulin resistance and mitochondrial dysfunction in the liver-brain axis. Food Funct. 2019; 10(4): 2125-2137. doi: 10.1039/c8fo02460j

90. Hollman PCH, Cassidy A, Comte B, Heinonen M, et al. The biological relevance of direct antioxidant effects of polyphenols for cardiovascular health in humans is not established. $J$ Nutr. 2011; 141(5): 989S-1009S. doi: 10.3945/jn.110.131490

91. Naz A, Butt MS, Sultan MT, Qayyum MM, Niaz RS. Watermelon lycopene and allied health claims. EXCLI J. 2014; 13: 650660.

92. Nakamura A, Itaki C, Saito A, et al. Possible benefits of tomato juice consumption: A pilot study on irradiation human lymphocytes from healthy donors. Nutr J. 2017; 16(1): 27. doi: 10.1186/s12937-017-0248-3

93. Devaraj S, Mathur S, Basu A, Aung HH, Vasu VT, Meyers S, Jialal I. A dose-response study on the effects of purified lycopene supplementation on biomarkers of oxidative stress. J Am Coll Nutr. 2008; 27: 267-273. doi: 10.1080/07315724.2008.10719699

94. Panasenko OM, Sharov VS, Briviba K, Sies H. Interaction of peroxynitrite with carotenoids in human low density lipoproteins. Arch Biochem Biophys. 2000; 373: 302-305. doi: 10.1006/ abbi.1999.1424

95. Paran E, Novack V, Engelhard YN, Hazan-Halevy I. The effects of natural antioxidants from tomato extract in treated but uncontrolled hypertensive patients. Cardiovasc Drugs Ther. 2009; 23: 145-151. doi: 10.1007/s10557-008-6155-2

96. Engelhard YN, Gazer B, Paran E. Natural antioxidants from 
tomato extract reduce blood pressure in patients with grade- 1 hypertension: A double-blind, placebo-controlled pilot study. Am Heart J. 2006; 151: 100. doi: 10.1016/j.ahj.2005.05.008

97. Palozza P, Catalano A, Simone RE, Mele MC, Cittadini A. Effect of lycopene and tomato products on cholesterol metabolism. Ann Nutr Metab. 2012; 61: 126-134. doi: 10.1159/000342077

98. Misra R, Mangi S, Joshi S, Mittal S, Gupta SK, Pandey RM. LycoRed as an alternative to hormone replacement therapy in lowering serum lipids and oxidative stress markers: a randomized controlled clinicaltrial. J Obstet Gynaecol Res. 2006; 32: 299-304. doi: 10.1111/j.1447-0756.2006.00410.x

99. Kumar R, Salwe KJ, Kumarappan M. Evaluation of Antioxidant, hypolipidemic, and antiatherogenic property of lycopene and astaxanthin in atherosclerosis-induced rats. Pharmacognosy Res. 2017; 9(2): 161-167. doi: 10.4103/0974-8490.204654

100. Brito AK, Lima G, Farias LM, et al. Lycopene-rich extract from red guava (Psidium guajava L.) decreases plasma triglycerides and improves oxidative stress biomarkers on experimentally-induced dyslipidemia in hamsters. Nutrients. 2019; 11(2): 393. doi: $10.3390 /$ nu11020393

101. Iwamoto A, Kajikawa M, Maruhashi T, et al. Vascular function and intima-media thickness of a leg artery in peripheral artery disease: A comparison of buerger disease and atherosclerotic peripheral artery disease. J Atheroscler Thromb. 2016; 23(11): 12611269. doi: $10.5551 /$ jat.35436

102. O'Leary DH, Polak JF, Kronmal RA, et al. Thickening of the carotid wall. A marker for atherosclerosis in the elderly ? Cardiovascular Health Study Collaborative Research Group. Stroke. 1996; 27: 224-231. doi: 10.1161/01.str.27.2.224

103. Lind L. Flow-mediated vasodilation was found to be an independent predictor of changes in the carotid plaque status during a 5-year follow-up. J Atheroscler Thromb. 2014; 21: 161-168. doi: $10.5551 /$ jat. 18572

104. Gianetti J, Pedrinelli R, Petrucci R, et al. Inverse association between carotid intima-media thickness and the antioxidant lycopene in atherosclerosis. Am Heart J. 2002; 143(3): 467-474. doi: $10.1067 / \mathrm{mhj} .2002 .120776$

105. Riccioni G, Orazio DN, Palumbo N, et al. Relationship between plasma antioxidant concentrations and carotid intima-media thickness: The Asymptomatic Carotid Atherosclerotic Disease in Manfredonia Study. Eur J Cardiovasc Prev Rehabil. 2009; 16(3): 351-357.

106. Karppi J, Kurl S, Ronkainen K, Kauhanen J, Laukkanen JA. Serum carotenoids reduce progression of early atherosclerosis in the carotid artery wall among Eastern Finnish men. PLoS One. 2013; 8(5): e64107. doi: 10.1371/journal.pone.0064107

107. Zou ZY, Xu XR, Lin XM, et al. Effects of lutein and lyco- pene on carotid intima-media thickness in Chinese subjects with subclinical atherosclerosis: a randomised, double-blind, placebo-controlled trial. Br J Nutr. 2014; 111(3): 474-480. doi: 10.1017 / S0007114513002730

108. Elvira-Torales LI, García-Alonso J, Periago-Castón MJ. Nutritional importance of carotenoids and their effect on liver health: A review. Antioxidants (Basel). 2019; 8(7). pii: E229. doi: 10.3390 /antiox 8070229

109. Gyamfi D, Patel V. Liver metabolism: Biochemical and molecular regulations. In: Preedy VR, Lakshman R, Srirajaskanthan R, Watson RR, eds. Nutrition, Diet Therapy, and the Liver. 1st ed. Boca Raton, FL, USA: CRC Press; 2017: 3-15.

110. Wilkins T, Tadkod A, Hepburn I, Schade RR. Nonalcoholic fatty liver disease: Diagnosis and management. Am Fam Physician. 2013; 88(1): 35-42.

111. Eritja N, Arjó G, Santacana M, et al. Oral intake of genetically engineered high-carotenoid corn ameliorates hepatomegaly and hepatic steatosis in PTEN haploinsufficient mice. Biochimica et Biophysica Acta (BBA) - Molecular Basis of Disease. 2016; 1862(4): 526-535. doi: 10.1016/j.bbadis.2016.01.018

112. Younossi ZM, Koenig AB, Abdelatif D, Fazel Y, Henry L, Wymer M. Global epidemiology of nonalcoholic fatty liver disease - meta-analytic assessment of prevalence, incidence, and outcomes. Hepatology. 2016; 64(1): 73-84. doi: 10.1002/hep.28431

113. Kim AY, Jeong YJ, Park YB, et al. Dose dependent effects of lycopene enriched tomato-wine on liver and adipose tissue in high-fat diet fed rat. Food Chem. 2012; 130(1): 42-48. doi: 10.1016/j.foodchem.2011.06.050

114. Xiao ML, Chen GD, Zeng FF, et al. Higher serum carotenoids associated with improvement of non-alcoholic fatty liver disease in adults: A prospective study. Eur J Clin Nutr. 2018; 58(2): 721-730. doi: 10.1007/s00394-018-1678-1

115. Lim JY, Liu C, Hu KQ, et al. Dietary $\beta$-cryptoxanthin inhibits high-refined carbohydrate diet-induced fatty liver via differential protective mechanisms depending on carotenoid cleavage enzymes in male mice. J Nutr. 2019; 149(9): 1553-1564. doi: $10.1093 /$ jn/nxz106

116. Bandeira ACB, da Silva RC, Rossoni JV Júnior, et al. Lycopene pretreatment improves hepatotoxicity induced by acetaminophen in C57BL/ 6 mice. Bioorg Med Chem. 2017; 25(3): $1057-$ 1065. doi: 10.1016/j.bmc.2016.12.018

117. Yilmaz B, Sahin K, Bilen H, et al. Carotenoids and non-alcoholic fatty liver disease. Hepatobiliary Surg Nutr. 2015; 4: 161-171. doi: $10.3978 /$ j.issn.2304-3881.2015.01.11

118. Heber D, Lu QY. Overview of mechanisms of action of lycopene. Exp Biol Med. 2002; 227: 920-923. doi: $10.1177 / 153537020222701013$ 


\section{$10.1007 / \mathrm{s} 00394-014-0770-4$}

119. Stahl W, Heinrich U, Aust O, Tronnier H, Sies H. Lyco pene-rich products and dietary photoprotection. Photochem Photobiol Sci. 2006; 5(2): 238-242. doi: 10.1039/b505312a

120. Bahcecioglu IH, Kuzu N, Metin K, et al. Lycopene prevents development of steatohepatitis in experimental nonalcoholic steatohepatitis model induced by high-fat diet. Vet Med Int. 2010; 2010. pii:262179. doi: $10.4061 / 2010 / 262179$

121. Chung J, Koo K, Lian F, et al. Apo-10'-lycopenoic acid, a lycopene metabolite, increases sirtuin $1 \mathrm{mRNA}$ and protein levels and decreases hepatic fat accumulation in ob/ob mice. J Nutr. 2012; 142: 405-410. doi: 10.3945/jn.111.150052

122. Ahn J, Lee H, Jung CH, et al. Lycopene inhibits hepatic steatosis via microRNA-21-induced downregulation of fatty acid-binding protein 7 in mice fed a high-fat diet. Mol Nutr Food Res. 2012; 56: 1665-1674. doi: 10.1002/mnfr.201200182

123. Wang Y, Ausman LM, Greenberg AS, et al. Dietary lycopene and tomato extract supplementations inhibit nonalcoholic steatohepatitis-promoted hepatocarcinogenesis in rats. Int J Cancer. 2010; 126: 1788-1796. doi: 10.1002/ijc.24689

124. Ip BC, Hu KQ, Liu C, et al. Lycopene metabolite, apo-10'-lycopenoic acid, inhibits diethylnitrosamine-initiated, high fat diet-promoted hepatic inflammation and tumorigenesis in mice. Cancer Prev Res (Phila). 2013; 6(12): 1304-1316. doi: 10.1158/19406207.CAPR-13-0178

125. Wang J, Zou Q, Suo Y, et al. Lycopene ameliorates systemic inflammation-induced synaptic dysfunction via improving insulin resistance and mitochondrial dysfunction in the liverbrain axis. Food Funct. 2019; 10(4): 13. doi: 10.1039/C8FO02460J

126. Shimizu Y, Mashima-Nemoto T, Hazawa M, et al. The hepatoprotective effect of lycopene on Con A-induced liver injury in mice. Pharmazie. 2018; 73(7): 393-395. doi: 10.1691/ ph.2018.8437

127. Li CC, Liu C, Fu M, et al. Tomato powder inhibits hepatic steatosis and inflammation potentially through restoring SIRT1 activity and adiponectin function independent of carotenoid cleavage enzymes in mice. Mol Nutr Food Res. 2018; 62(8): e1700738. doi: 10.1002/mnfr.201700738

128. Sadek K, Lebda M, Abouzed T, Nasr S, EL-Sayed Y. The molecular and biochemical insight view of lycopene in ameliorating tramadol-induced liver toxicity in a rat model: implication of oxidative stress, apoptosis, and MAPK signaling pathways. Environ Sci Pollut Res Int. 2018; 25(33): 33119-33130. doi: 10.1007/ s11356-018-3265-7

129. Martín-Pozuelo G, Navarro-González I, González-Barrio R, et al. The effect of tomato juice supplementation on biomarkers and gene expression related to lipid metabolism in rats with induced hepatic steatosis. Eur J Nutr. 2015; 54(6): 933-944. doi:
130. Bernal C, Martín-Pozuelo G, Lozano AB, et al. Lipid biomarkers and metabolic effects of lycopene from tomato juice on liver of rats with induced hepatic steatosis. J Nutr Biochem. 2013; 24(11): 1870-1881. doi: 10.1016/j.jnutbio.2013.05.003

131. Karaca A, Yilmaz S, Kaya E, Altun S. The effect of lycopene on hepatotoxicity of aflatoxin B1 in rats. Arch Physiol Biochem. 2019: 1-8. doi: 10.1080/13813455.2019.1648516

132. Zeb A, Haq I. The Protective Role of tomato powder in the toxicity, fatty infiltration and necrosis induced by oxidized tallow in rabbits. J Food Biochem. 2016; 40(4): 428-435. doi: 10.1111/ jfbc. 12234

133. Piña-Zentella RM, Rosado JL, Gallegos-Corona MA, Madrigal-Pérez LA, García OP, Ramos-Gomez M. Lycopene improves diet-mediated recuperation in rat model of nonalcoholic fatty liver disease. J Med Food. 2016; 19(6): 607-614. doi: 10.1089/ jmf.2015.0123

134. Kanitakis, J. Anatomy, histology and immunohistochemistry of normal human skin. Eur J Dermatol. 2002; 12(4); 390-401.

135. Baumann L. Skin ageing and its treatment. J Pathol. 2007; 211(2): 241-251. doi: 10.1002/path.2098

136. Trautinger F. Mechanisms of photodamage of the skin and its functional consequences for skin ageing. Clin Exp Dermatol. 2001; 26: 573-577. doi: 10.1046/j.1365-2230.2001.00893.x

137. Svobodová A, Psotová J, Walterová D. Natural phenolics in the prevention of UV-induced skin damage. A review. Biomed Pap Med Fac Univ Palacky Olomouc Czech Repub. 2003; 147(2): 137-145. doi: $10.5507 /$ bp.2003.019

138. Afaq F, Mukhtar H. Botanical antioxidants in the prevention of photocarcinogenesis and photoaging. Exp Dermatol. 2006; 15 (9): 678-684. doi: 10.1111/j.1600-0625.2006.00466.x

139. Darvin ME, Sterry W, Lademann J, Vergou T. The role of carotenoids in human skin. Molecules. 2011; 16(12): 10491-10506. doi: 10.3390/molecules161210491

140. Meinke MC, Darvin ME, Vollert H, Lademann J. Bioavailability of natural carotenoids in human skin compared to blood. Eur J Pharm Biopharm. 2010; 76: 269-274. doi: 10.1016/j. ejpb.2010.06.004

141. Evans JA, Johnson EJ. The role of phytonutrients in skin health. Nutrients. 2010; 2(8): 903-928. doi: 10.3390/nu2080903

142. Ribaya-Mercado D, Garmyn M, Gilchrest BA, Russell RM. Skin lycopene is destroyed preferentially over $\beta$-carotene during ultraviolet irradiation in humans. J Nutr. 1995; 125(7): 1854-1859. doi: $10.1093 /$ jn/125.7.1854 
143. Scarmo S, Cartmel B, Lin H, et al. Significant correlations of dermal total carotenoids and dermal lycopene with their respective plasma levels in healthy adults. Arch Biochem Biophys. 2010; 504: 34-39. doi: 10.1016/j.abb.2010.07.004

144. Darvin M, Patzelt A, Gehse S, et al. Cutaneous concentration of lycopene correlates significantly with the roughness of the skin. Eur J Pharm Biopharm. 2008; 69(3): 943-947. doi: 10.1016/j. ejpb.2008.01.034

145. Stahl W, Heinrich U, Wiseman S, Eichler O, Sies H, Tronnier H. Dietary tomato paste protects against ultraviolet light-induced erythema in humans. J Nutr. 2001; 131(5): 1449-1451. doi: 10.1093/jn/131.5.1449

146. Césarini JP, Michel L, Maurette JM, Adhoute H, Béjot M. Immediate effects of UV radiation on the skin: Modification by an antioxidant complex containing carotenoids. Photodermatol Photoimmunol Photomed. 2003; 19(4): 182-189. doi: 10.1034/j.16000781.2003.00044.x

147. Heinrich U, Gärtner C, Wiebusch M, et al. Supplementation with beta-carotene or a similar amount of mixed carotenoids protects humans from UV-induced erythema. J Nutr. 2003; 133(1): 98-101. doi: 10.1093/jn/133.1.98

148. Greul AK, Grundmann JU, Heinrich F, et al. Photoprotec- tion of UV-irradiated human skin: An antioxidative combination of vitamins $\mathrm{E}$ and $\mathrm{C}$, carotenoids, selenium and proanthocyanidins. Skin Pharmacol Appl Skin Physiol. 2002; 15(5): 307-315. doi: $10.1159 / 000064534$

149. Koul A, Bansal MP, Chaudhary H, Chugh NA. Lycopene enriched tomato extract suppresses chemically induced skin tumorigenesis in mice. Int J Vitam Nutr Res. 2019: 1-21. doi: 10.1024/0300-9831/a000597

150. Eichler O, Sies H, Stahl W. Divergent optimum levels of lycopene, beta-carotene and lutein protecting against UVB irradiation in human fibroblasts. Photochem Photobiol. 2002; 75: 503-506. doi: 10.1562/0031-8655(2002)075<0503:dololc >2.0.co;2

151. Rizwan M, Rodriguez-Blanco I, Harbottle A, Birch-Machin MA, Watson RE, Rhodes LE. Tomato paste rich in lycopene protects against cutaneous photodamage in humans in vivo: a randomized controlled trial. Br J Dermatol. 2011; 164: 154-162. doi: 10.1111/j.1365-2133.2010.10057.x

152. Grether-Beck S, Marini A, Jaenicke T, Stahl W, Krutmann J. Molecular evidence that oral supplementation with lycopene or lutein protects human skin against ultraviolet radiation: Results from a double-blinded, placebo-controlled, crossover study. $\mathrm{Br} J$ Dermatol. 2017; 176: 1231-1240. doi: 10.1111/bjd.15080 